\title{
Pengaruh Material Konservasi Kolostrum terhadap Pelepasan Ion $\mathrm{Ni}$
}

\author{
The Influence of Colostrum Conservation on Ni lon Release
}

\author{
*Grahita Aditya, Hikmah Nuraini, dan Whinahyu Aji Sekarini \\ Fakultas Kedokteran Gigi Universitas Islam Sultan Agung
}

Submitted: 31-07-2018; Revised: 21-08-2018; Accepted: 27-12-2018

\begin{abstract}
Nickel in orthodontic bracket will be released immediately in the oral cavity. The release of $N i$ ion may trigger type $I V$ hypersensitivity reaction. Colostrum has a high content of lactoferrin which can inhibit $T$ cells proliferation after nickel sensitization, and decrease oxidative stress. Adding potassium sorbat $0.5 \%$, or fermentation of colostrum may extend colostrum storage. The purpose of this research is to know the difference of nickel ion release in colostrum with $0.5 \%$ potassium sorbat addition and fermented colostrum. Methods of the study were laboratory experimental with four groups, colostrum and $0.5 \%$ potassium sorbat, fermented colostrum, sodium fluoride and artificial saliva. The sample was incubated in $40^{\circ} \mathrm{C}$ for 7 days. Nickel ions was measured using an inductively coupled plasma-optical emission spectrophotometry (ICP-OES Perlun Elmer Optima 8300 ${ }^{\circledR}$ ). Ni ions release differences were tested using the Kruskall-Wallis and Mann Whitney test.The lowest rate of Ni ion release was found in the colostrum group with $0.5 \%$ potassium sorbat followed by the fermented colostrum group. KruskalWallis test no significant difference $(p>0,05)$ in each study group. The Mann Whitney test found significant differences between colostrum solution with $0.5 \%$ potassium sorbat and sodium fluoride, and also artificial saliva. The results concluded that colostrum with $0.5 \%$ potassium sorbat inhibit the release of $\mathrm{Ni}$ ions.
\end{abstract}

Keywords: Colostrum with potassium sorbat 0,5\%; Fermented colostrum; Ion Ni; Stainless steel orthodontic brackets.

\begin{abstract}
ABSTRAK
Braket ortodonti mengandung Ni yang akan terlepas ke dalam rongga mulut. Lepasnya ion Ni dapat memicu reaksi hipersensitivitas. Kolostrum sapi memiliki kandungan laktoferin tinggi yang dapat menurunkan proliferasi sel T karena nikel, dan mampu menurunkan stres oksidatif. Penambahan potassium sorbat $0,5 \%$, atau melakukan fermentasi terhadap kolostrum dapat meningkatkan daya simpan kolostrum tanpa merusak kandungan protein. Tujuan dari penelitian ini mengetahui perbedaan pelepasan ion nikel pada kolostrum dengan penambahan potassium sorbat $0,5 \%$ dan kolostrum terfermentasi. Penelitian ini merupakan eksperimental laboratoris menggunakan empat kelompok perlakuan yaitu kolostrum dengan potassium sorbat $0,5 \%$, kolostrum terfermentasi, sodium fluoride dan saliva buatan. Sampeldiinkubasidengansuhu $4^{0}$ selama7hari.Pengukuranionnikeldiukurmenggunakan alat inductively coupled plasma - optical emission spectrophotometry (ICP-OES Perlun Elmer Optima 8300 ${ }^{\circledR}$. Perbedaan pelepasan ion Ni pada masing-masing kelompok diuji menggunakan uji Kruskall-Wallis dan Mann Whitney. Rerata pelepasan ion Ni terendah terdapat pada kelompok kolostrum dengan
\end{abstract}

${ }^{*}$ Corresponding author: grahita@unissula.ac.id.

Copyright (C) 2019 THE AUTHOR(S). This article is distributed under a Creative Commons Attribution-Share Alike 4.0 International license. Jurnal Teknosains is published by the Graduate School of Universitas Gadjah Mada. 
potassium sorbat $0,5 \%$ diikuti oleh kelompok kolostrum terfermentasi. Uji Kruskal-Wallis tidak didapatkan perbedaan yang signifikan $(p>0,05)$ pada masing-masing kelompok penelitian. Uji Mann Whitney menemukan perbedaan yang signifikan antara larutan kolostrum dengan potassium sorbat $0,5 \%$ dan sodium fluoride, serta saliva buatan. Hasil penelitian menyimpulkan bahwa kolostrum dengan potassium sorbat $0,5 \%$ mampu menghambat pelepasan ion $\mathrm{Ni}$.

Kata Kunci: Braket stainless steel; Ion Ni; Kolostrum dengan potassium sorbat 0,5\%; Kolostrum terfermentasi.

\section{PENGANTAR}

Riset Kesehatan Dasar Nasional tahun 2013 menunjukkan proporsi maloklusi penduduk Indonesia sebesar $14,3 \%$. Perawatan ortodonti adalah solusi dalam penanganan maloklusi. Perawatan ortodonti cekat memiliki risiko dan komplikasi, antara lain timbulnya reaksi hipersensitivitas. Prevalensi hipersensitivitas kontak nikel adalah lebih dari 10\%, dengan kecenderungan lebih umum pada wanita.[1]

Braket ortodonti, salah satu komponen perawatan ortodonti, harus memiliki kekuatan, dimensi yang akurat, dan ketahanan terhadap korosi.[2] Braket stainless steel, mengandung nikel (Ni) dan kromium (Cr), dipasangkan pada gigi pasien selama 1-2 tahun akan berinteraksi dengan lingkungan rongga mulut sehingga terjadi korosi. Pelepasan logam kromium dan nikel yang dapat masuk ke dalam tubuh maupun berkontak langsung dengan jaringan. [3]

Peningkatan ion nikel terjadi segera setelah pemasangan alat ortodonti cekat, namun jumlah kadar ion $\mathrm{Ni}$ yang terlepas pada saliva tersebut tidak signifikan. Angka pelepasan ion nikel dari alat ortodonti di bawah kebutuhan nutrisi harian, walaupun demikian kontak ion Ni terhadap jaringan dapat memicu hipersensitivitas tipe kontak terutama pada individu dengan patch test positif terhadap Ni.[4]

Pelepasan ion pada alat ortodonti dapat menimbulkan dampak merugikan untuk kesehatan maupun perubahan dari sifat fisis dan mekanis alat tersebut. Proses korosi tersebut menimbulkan perubahan warna permukaan logam, pengurangan kekuatan dan perubahan dimensi logam, dan penambahan gesekan/friksi. Reaksi hipersensitivitas tipe IV dengan reaksi imun seluler atau delayed type hypersensitivity yang dimediasi oleh sel $\mathrm{T}$ dan monosoit/makrofag juga dapat terjadi akibat ion Ni yang terlepas dari kawat ataupun braket ortodonti.[5]

Reaksi hipersensitivitas tipe IV karena ion $\mathrm{Ni}$ dimediasi oleh hapten. Ion nikel akan diikat oleh protein menjadi antigen. Hapten mengikat molekul peptida-MHC yang bermigrasi ke kelenjar limfa dan membawa antigen pada sel $\mathrm{T}$ naive yang berdifferensiasi menjadi sel $\mathrm{T}$ CD4+ dan CD8+ spesifik Ni. Sel T CD8 akan melepaskan sitokin IFN-Y dan TNF-a hingga makrofag teraktivasi.[6,7]

Penggunaan inhibitor korosi merupakan pilihan baik dalam mencegah terjadinya kerusakan logam, namun toksisitas akibat bahan inhibitor korosi harus dipertimbangkan dalam penggunaannya pada tubuh manusia. Inhibitor korosi dari bahan alami bersifat biodegradable, tanpa kandungan logam berat maupun komponen toksik lainnya. Kolostrum merupakan salah satu bahan alami yang memiliki potensi anti korosi.[8]

Kolostrum adalah susu pertama yang dihasilkan setelah melahirkan. Kolostrum sapi perah (bovine colostrum) memiliki kandungan immonoglobulin, laktoferin, laktoperoksida, lisosim, vitamin, mineral, lemak dan mikroba. Kolostrum sapi memiliki banyak potensi manfaat yang belum digali, termasuk sebagai anti-korosi. Kolostrum murni memiliki ketahanan hanya selama 1 hari. Konservasi kolostrum salah satunya dilakukan dengan fermentasi. Fermentasi menyebabkan berkembangnya mikroorganisme yang menguntungkan dan dapat mereduksi $\mathrm{pH}$. Kondisi penyimpanan fermentasi kolostrum tampak berbeda, terutama pada suhu kamar. Penyimpanan fermentasi kolostrum umumnya pada suhu di bawah $25^{\circ} \mathrm{C}$. Fermentasi dilakukan sebagai alternatif karena tidak menyebabkan terpecahnya agregat protein, dimana terjadi ketika kolostrum dipanaskan. Komponen kolostrum berubah beberapa hari 
setelah fermentasi dengan penurunan laktosa dan protein. [4-7]

Kolostrum segar mengandung 100.000 $\mathrm{cfu} / \mathrm{ml}$ bakteri, bahkan mengandung beberapa bakteri infeksius seperti mycoplasma, salmonella, dan lain-lain yang akan berkembang biak pada suhu normal $\left( \pm 23^{\circ} \mathrm{C}\right)$, dan semakin pelan perkembangbiakannya jika disimpan di dalam kulkas, sehingga memerlukan pengolahan tertentu sebelum dikonsumsi oleh manusia. Penambahan potassium sorbat 0,5\% mampu menghambat proliferasi bakteri pada kolostrum. Kolostrum dengan pengawet potasium sorbat 0,5\% dapat bertahan 6-7 hari, bahkan potasium sorbat memiliki sifat inhibitor korosi. Penyimpanan kolostrum selama 6-7 hari dengan penmbahan postassium sorbat $0,5 \%$ tidak mengubah viskositas kolostrum dan tidak terjadi kerusakan pada igG dari kolostrum. [8-10]

Pemberian laktoferin mampu menurunkan proliferasi sel $\mathrm{T}$ dan sitokin IL-5, dan CCR4 pada aktivasi sel $\mathrm{T}$ karena nikel. Laktoferin mampu meningkatkan ekspresi CD86 pada sel dendritik terstimulasi nikel sulfat. Laktoferin dapat berfungsi sebagai faktor maturasi sel dendritik dengan meningkatkan ekspresi marker maturasi seperti, HLA II, CD80, CD86, dan CD83.[11]

Saliva buatan (larutan McDougall) berfungsi sebagai larutan buffer dalam medium atau pengganti fungsi saliva. Pembuatan saliva buatan yang digunakan dalam penelitian ini adalah dengan metode Fusayama Meyer. Komposisi saliva buatan tersebut menyerupai dengan saliva asli.[10]

Fluoride adalah senyawa kimia yang memiliki sifat elektronegatif diantara semua senyawa kimia. Fluoride yang biasa dipergunakaan dalam sediaan obat kumur, pasta gigi, dan prophylactic gels. Fluoride dalam sediaan obat kumur biasa digunakan oleh masyarakat pengguna ortodontik untuk menjaga kebersihan rongga mulut. Kandungan sodium fluoride atau ion fluoride yang terdapat dalam obat kumur, pasta gigi dan prophylactic gels dapat menyebabkan degradasi permukaan stainless steel yang dapat memperberat terjadinya pelepasan ion logam. [12]
Penelitian ini ditujukan untuk mengetahui perbedaan pelepasan ion Ni pada braket metal dalam perendaman fermentasi kolostrum, kolostrum dengan potassium sorbat $0,5 \%$, sodium fluoride, dan saliva buatan.

\section{Metode}

Jenis penelitian ini adalah eksperimental laboratorium murni dengan rancangan post test only control group design. Penelitian dilakukan di labratorium kimia Fakultas MIPA Universitas Negeri Semarang pada bulan Maret 2018.

Penelitian dilakukan dengan mengukur pelepasan ion $\mathrm{Ni}$ pada perendaman braket stainless steel American Orthodontic ${ }^{\circledR}$. Kelompok penelitian terdiri dari empat kelompok besar terdapat kelompok kolostrum dengan potassium sorbat $0,5 \%$, kolostrum terfermentasi perlakuan, kontrol negatif (saliva buatan) dan kontrol positif (sodium fluoride). Sampel diuji menggunakan alat inductively coupled plasma-optical emission spectrophotometry (ICPOES). Teknik penelitian ini menggunakan simple random sampling dengan penentuan besar sampel dilakukandengan menggunakan rumus Federer sebesar 24 sampel (6 sampel per kelompok).

Kolostrum pada penelitian ini menggunakan kolostrum sapi murni yang diambil pada hari pertama pasca melahirkan, berbentuk cairan kuning dan kental, dari peternakan Koperasi Wahyu Agung Dusun Bumiharjo, Getasan, Salatiga. Penambahan potassium sorbat 0,5\% dilakukan segera setelah kolostrum didapatkan. Fermentasi dilakukan dengan pemberian bakteri Lactobacillus spp. Saliva buatan dibuat dengan metode Fusayama Meyer yang kandungannya hampir sama dengan saliva alami dengan $\mathrm{pH}$ 7. Sodium Fluoride dibuat dengan pengenceran serbuk $\mathrm{NaF}$ dalam akuades dengan konsentrasi $0,2 \%$.

Pengambilan kolostrum dilakukan dengan cara pemerasan pada sapi hari pertama pasca melahirkan. Kolostrum kemudian dibekukan pada suhu $-5^{\circ} \mathrm{C}$. Kolostrum yang akan digunakan untuk perendaman sebelumnya dilakukan pencairan dengan menggunakan suhu ruangan. 
Fermentasi kolostrum dilakukan dengan memanaskan $500 \mathrm{ml}$ kolostrum dengan cara memasukkan susu kedalam erlenmeyer, kemudian erlenmeyer ini dimasukan kedalam panci besar yang telah berisi air hingga suhunya kurang lebih $90^{\circ} \mathrm{C}$ selama 15 menit. Kolostrum didinginkan sampai suhu mencapai $45^{\circ} \mathrm{C}$, lalu ditambahkan starter Streptococcus thermophilus dan Lactobacillus bulgaricus sebanyak 3-5\% sedikit demi sedikit sambil diaduk supaya larut. Kolostrum diletakkan ke dalam wadah-wadah steril yang sudah disiapkan, kemudian tutup dengan aluminium foil dan di inkubasikan pada suhu $43^{\circ} \mathrm{C}$ selama 4 jam atau pada suhu kamar selama 18 jam. Setelah inkubasi selesai, fermentasi kolostrum yang dihasilkan segera didinginkan dalam lemari es atau dipasteurisasikan pada suhu $65^{\circ} \mathrm{C}$ selama 30 menit.

Sebelum penelitian dilakukan penimbangan braket dan secara dibagi secara seimbang ke dalam kelompok. Perendaman braket dilakukan selama 7 hari dalam suhu $4^{\circ} \mathrm{C}$. Setelah perendaman selesai dilakukan, masingmasing larutan disimpan pada suhu $0^{\circ} \mathrm{C}$ hingga pengukuran dilakukan.

Beberapa kreteria inklusi dan eksklusi diterapkan pada pemilihan sampel:

a. Braket metal jenis stainless steel dengan slot 0,22 " premolar rahang bawah dengan merek American Orthodontic (AO).

b. Kesesuaian berat setiap braket

c. Adanya bopeng atau cacat pada braket

d. Terjadi perubahan warna yang tidak sesuai pada braket (misalnya : warna braket abuabu cerah berubah menjadi hitam seperti terbakar)

Besar pelepasan ion $\mathrm{Ni}$ didapatkan dari selisih kadar ion Ni dalam wadah besar sebelum larutan dibagi ke dalam 6 tabung borosilicate dan setelah perendaman braket metal stainless steel pada masing-masing tabung. Kadar ion dianalisa dengan inductively coupled plasma optical emission spectrophotometry (ICP-EOS) Perlun Elmer Optima 8300 dengan satuan pengukuran $\mathrm{mg} / \mathrm{L}$, skala numerik. Braket yang digunakan dalam penelitian ini adalah braket metal American Orthodontic ${ }^{\circledR}$ premolar rahang bawah kanan slot 0,22 " dengan berat $\pm 0,3$ gr.
Data hasil penelitian ditabulasi, kemudian dilakukan analisa statistik menggunakan SPSS 12.0 dengan uji Kruskal Wallis dilanjutkan dengan uji Mann Whitney.

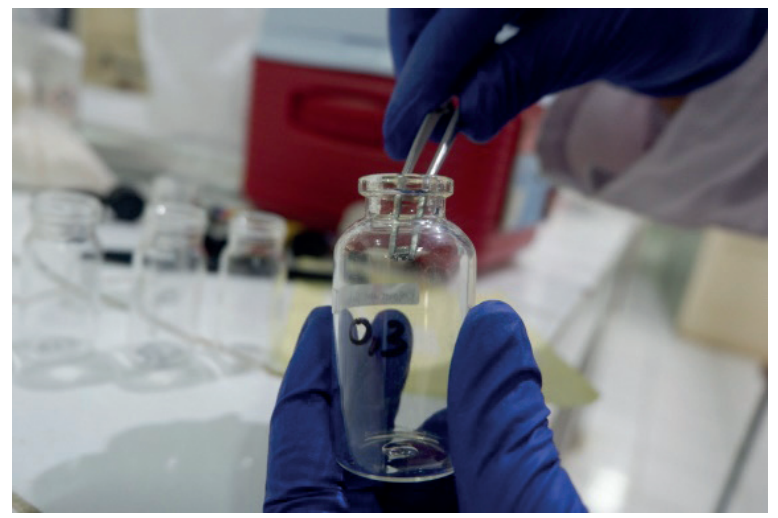

Gambar 1.

Spesimen Braket (Sumber: dokumentasi pribadi)

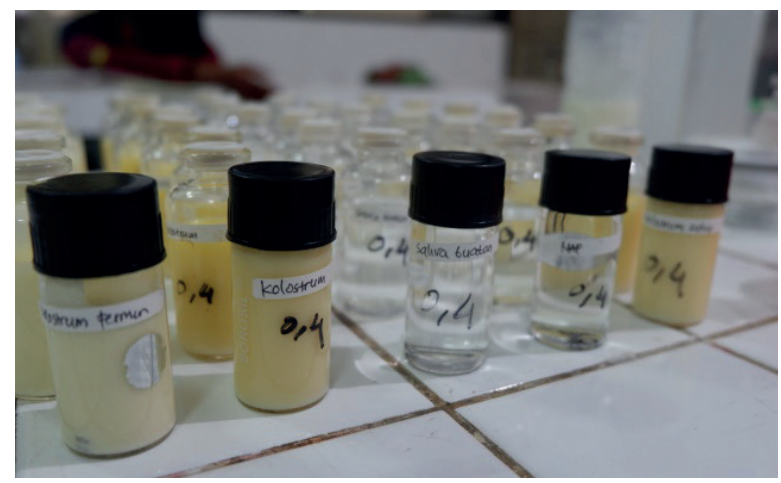

Gambar 2.

Perendaman Spesimen dalam Larutan Kolostrum

(Sumber: dokumentasi pribadi)

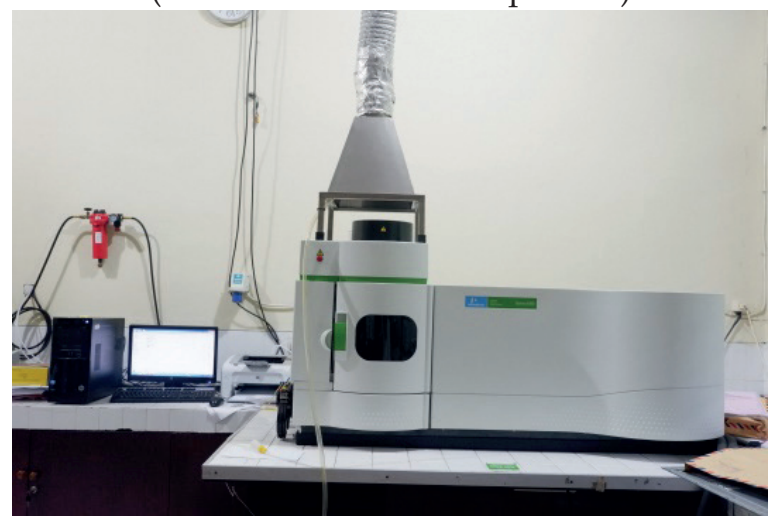

Gambar 3

ICP-EOS untuk Mengukur Kadar Ion Ni dalam Kelompok Perlakuan (Sumber: dokumentasi pribadi) 
Tabel 1.

Rerata dan Standar Deviasi Jumlah Pelepasan Ion Ni (mg/L)

\begin{tabular}{ll}
\hline \multicolumn{1}{c}{ Kelompok } & Jumlah Pelepasan Ion Ni \\
\hline P1 & $0,0125 \pm 0,0306$ \\
\hline P2 & $0,0158 \pm 0,0303$ \\
\hline P3 & $0,0453 \pm 0,0639$ \\
\hline P4 & $0,0752 \pm 0,0606$ \\
\hline Keterangan & $\begin{array}{l}\text { P1: Kolostrum dengan potassium sorbat 0,5\%; P2: } \\
\text { Kolostrum terfermentasi; P3: Saliva buatan; P4: } \\
\text { Sodium fluoride }\end{array}$
\end{tabular}

Uji normalitas dan homogenitas menunjukkan data yang tidak homogen. Uji Kruskal Wallis menunjukkan signifikasi sebesar 0,061.

Tabel 2.

Hasil Uji Normalitas dan Homogenitas Varian Data

\begin{tabular}{|c|c|c|}
\hline Kelompok & Uji Shapiro-Wilk & Uji Levene \\
\hline P1 & 0,001 & \multirow{4}{*}{0,020} \\
\hline $\mathrm{P} 2$ & 0,000 & \\
\hline P3 & $0,208^{*}$ & \\
\hline $\mathrm{P} 4$ & 0,011 & \\
\hline Keterangan : & $\begin{array}{l}\text { P1: Kolostrum dengan po } \\
\text { P2: Kolostrum terfermentas } \\
\text { P4: Sodium fluoride;:: distri } \\
\text { homogen }(p>0,05)\end{array}$ & $\begin{array}{l}\text { assium sorbat } 0,5 \% \\
\text { i; P3: Saliva buatan } \\
\text { busi data normal dar }\end{array}$ \\
\hline
\end{tabular}

Hasil analisis normalitas data tingkat pelepasan ion $\mathrm{Ni}$ pada braket metal stainless steel menunjukkan hanya kelompok saliva buatan yang memiliki distribusi data normal $(p>0,05)$, sedangkan ketiga kelompok lainnya tidak berdistribusi normal $(p<0,05)$. Varians data tingkat pelepasan ion $\mathrm{Ni}$ pada braket metal stainless steel pada keempat kelompok juga tidak homogen $(p<0,05)$

Normalitas sebaran/distribusi data dan homogenitas varian data tidak terpenuhi sehingga kebermaknaan perbedaan pelepasan ion logam pada braket metal stainless steel di keempat kelompok dianalisis secara non parametrik dengan uji Kruskal Wallis, dimana hasilnya ditunjukkan pada Tabel 3.

Tabel 3.

Hasil Analisis Perbedaan Pelepasan Ion Logam dengan Uji Kruskal Wallis

\begin{tabular}{cc}
\hline \multicolumn{1}{c}{ Kelompok } & Signifikansi (p) \\
\hline Kadar ion Ni & 0,328 \\
\hline
\end{tabular}

Uji Kruskal Wallis yang telah dilakukan menghasilkan nilai p sebesar 0,328 untuk ion $\mathrm{Ni}$ berarti tidak terdapat perbedaan pelepasan ion logam pada braket metal stainless steel antar keempat kelompok. Hipotesis dalam penelitian ini ditolak atau juga dapat dikatakan bahwa perendaman braket metal stainless steel dalam berbagai larutan tidak menghasilkan pelepasan ion logam braket metal stainless steel yang signifikan.

\section{Tabel 4.}

Uji Mann Whitney Jumlah Pelepasan Ion $\mathrm{Ni}(\mathrm{mg} / \mathrm{L})$

\begin{tabular}{lllll}
\hline Kelompok & \multicolumn{1}{c}{ P1 } & P2 & \multicolumn{1}{c}{ P3 } & \multicolumn{1}{c}{ P4 } \\
\hline P1 & - & 0,394 & $0,026^{*}$ & $0,041^{*}$ \\
\hline P2 & 0,394 & - & 0,310 & 0,132 \\
\hline P3 & $0,026^{*}$ & 0,310 & - & 0,699 \\
\hline P4 & $0,041^{*}$ & 0,132 & 0,699 & - \\
\hline Keterangan & $: \begin{array}{l}\text { P1: Kolostrum dengan potassium sorbat 0,5\%; P2: } \\
\text { Kolostrum terfermentasi; P3: Saliva } \\
\text { Sodium fluoride; * bermakna }\end{array}$ &
\end{tabular}

Hasil uji Mann Whitney menunjukkan signifikansi bermakna antara kelompok kolostrum dengan potassium sorbat 0,5\% dan saliva buatan, serta kolostrum dengan potassium sorbat $0,5 \%$ dengan sodium fluoride. Kelompok kolostrum dengan potassium sorbat $0,5 \%$ tidak berbeda bermakna dengan kolostrum terfermentasi, sedangkan kelompok kolostrum terfermentasi tidak berbeda bermakna dengan saliva buatan dan sodium fluoride.

\section{HASIL DAN PEMBAHASAN}

Prevalensi hipersensitivitas karena penggunaan alat orthodonti berbahan logam adalah sebesar 28,3\%, dan diduga juga terkait dengan penggunaan bahan-bahan logam dalam kehidupan sehari-hari. Prevalensi dermatitis kontak nikel secara umum adalah sebesar 4-5\%. Wanita memiliki kecenderungan lebih besar terhadap hipersensitivitas nikel karena frekuensi dan durasi kontak logam pada perhiasan, pakaian, maupun peralatan rumah tangga. [13,14]

Pemakaian braket dalam rongga mulut dipengaruhi oleh faktor-faktor lingkungan yaitu $\mathrm{pH}$, saliva, mikroorganisme, dan 
hipersensitivitas. Reaksi hipersensitivitas kontak dengan bahan logam dalam rongga mulut tersebut merupakan reaksi hipersensitivitas tipe IV. Mikroorganisme dalam rongga mulut dapat membentuk lapisan biofilm yang menyebabkan perubahan unsur kimia hingga terjadi reaksi oksidasi dan membuat ion logam braket terlepas ke dalam rongga mulut. Penggunaan bahan organik sebagai pelapis logam selain dapat mencegah kontak langsung juga akan secara perlahan melepaskan kandungan alaminya ke dalam rongga mulut. $[8,15,16]$

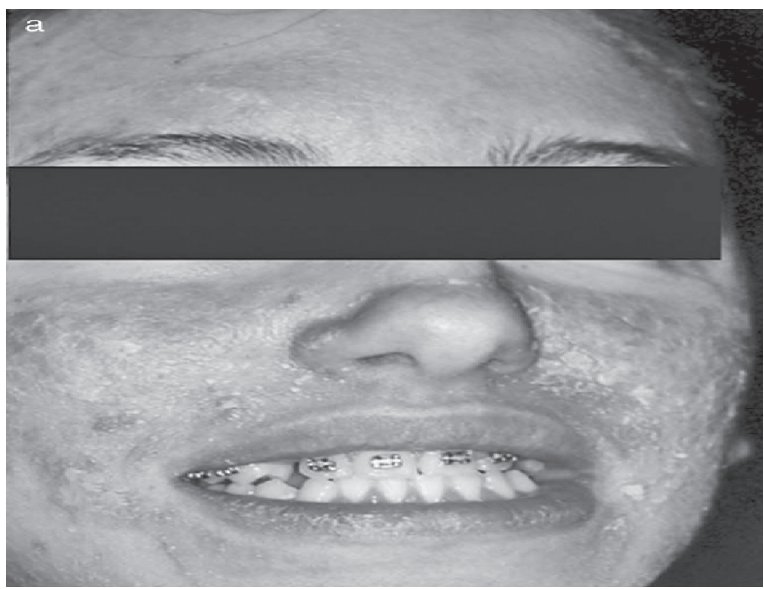

Gambar 4. Reaksi alergi yang disebabkan oleh alergi nikel

(Sumber: diambil dari Kolokitha dan Chatzistavrou, 2009 [17])

Hasil penelitian menunjukkan kolostrum dengan pengawet potassium sorbat 0,5\% mengeluarkan ion Ni paling sedikit. Potassium sorbat yang ditambahkan kedalam larutan kolostrum dapat mengurangi laju korosi pada braket. Kolostrum sapi mengandung lebih banyak ion $\mathrm{Na}, \mathrm{Cl}$, imunoglobulin, dan protein dibandingkan dengan susu sapi. $\mathrm{Na}$ dan $\mathrm{Cl}$ akan bereaksi dengan baja di mana anion tersebut akan menyerang lapisan oksida pada permukaan logam. Pelepasan ion pada perendaman kolostrum, baik dengan penambahan potassium sorbat $0,5 \%$ maupun terfermentasi, dapat terjadi karena kandungan natrium dan klorida dalam kolostrum. Potassium sorbat memiliki kemampuan inhibitor logam non-selektif. Potassium sorbat sangat efisien sebagai inhibitor korosi dalam larutan dengan pH 6 hingga 12. Penambahan potassium sorbat $0,3 \%$ mampu mengurangi laju korosi sebesar $67 \%$. Penambahan potassium sorbat $0,5 \%$ menambah daya simpan kolostrum hingga 6-7 hari, tanpa merubah viskositas dan tanpa merusak kandungan immunoglobulin. Tidak terdapat perubahan viskositas pada kolostrum dengan potassium sorbat $0,5 \%$ dan kolostrum terfermentasi setelah perendaman selama 7 hari.[18-21]

Potassium sorbat adalah zat tambahan yang sering digunakan sebagai pengawet makanan. Proporsi potassium sorbat dalam makanan yang dianjurkan adalah 0,05-0,1\%. Selain dengan potassium sorbat, keawetan makanan juga tergantung pada pengemasan dan kontaminasi. Penambahan anti mikroba sebagai pengawet juga menghambat pertumbuhan mikroba sehingga unutk memperlama keawetan makanan. [22]

Fermentasi kolostrum merupakan cara pengawetan dengan mempertahankan mikroorganisme baik, mereduksi $\mathrm{pH}$, sehingga kolostrum mampu bertahan suhu kamar lebih lama. Penurunan $\mathrm{pH}$ setelah fermentasi berarti kondisi kolostrum semakin asam, sehingga mempermudah terjadinya korosi, namun pelepasan ion Ni yang terjadi pada perendaman braket dalam kolostrum terfermentasi lebih kecil dari perendaman dalam sodium fluoride dan saliva buatan. Pelepasan ion $\mathrm{Ni}$ pada perendaman braket dalam sodium fluoride sangat bervariasi tergantung besar kandungan fluoride, pengenceran sodium fouride, dan $\mathrm{pH}$. Kandungan fluoride yang berlebihan mampu menyebabkan pelepasan ion $\mathrm{Ni}$ pada pengguna braket logam.[19,23-24]

Kandungan saliva buatan hampir sama dengan saliva rongga mulut. Saliva mengandung elektrolit seperti ion $\mathrm{H}^{+}$dan $\mathrm{Cl}^{-}$ sehingga menyebabkan reaksi elektro kimia dengan permukaan logam dan merusak lapisan pelindung logam. Pelepasan ion Ni pada braket yang direndam dalam saliva buatan bervariasi tergantung dari material braket, lama perendaman, elektrolit dan $\mathrm{pH}$ saliva buatan. Berkurangnya pelepasan ion $\mathrm{Ni}$ dalam rongga mulut diharapkan dapat mengurangi insidensi alergi dan toksisitas yang disebabkan oleh ion 
Ni. Komponen Ni merupakan agen sensitisasi imunologi kuat dan merupakan penyebab utama dermatitis kontak alergi.[19,265

Terdapat perbedaan pelepasan ion $\mathrm{Ni}$ pada perendaman braket dalam saliva buatan dengan $\mathrm{pH} 5$ dan 6,7. Pelepasan ion $\mathrm{Ni}$ ditemukan lebih tinggi pada $\mathrm{pH} 5$ lebih tinggi. Hal ini membuktikan bahwa kondisi yang semakin asam akan menyebabkan pelepasan ion lebih banyak. Penelitian ini menggunakan saliva buatan metode Fusayama Meyer dengan $\mathrm{pH}$ 7. Perbedaan $\mathrm{pH}$ mungkin mempengaruhi hasil pelepasan ion logam yang direndam dengan saliva buatan dengan $\mathrm{pH} 7$ sehingga hasil penelitian ini menunjukkan pelepasan ion logam pada kelompok saliva lebih kecil dibandingkan dengan penelitian lain dimana pada penelitian sebelumnya menunjukkan bahwa saliva buatan berpengaruhi dari pelepasan ion logam.[26]

Penelitian ini menunjukkan kelompok sodium fluoride memiliki pelepasan ion $\mathrm{Ni}$ tertinggi dibandingkan dengan kelompok fermentasi kolostrum. Hasil pra-penelitian dengan kolostrum tanpa dilakukan konservasi memperlihatkan perubahan konsistensi dari liquid ke solid. Pengukuran terhadap kadar ion $\mathrm{Ni}$ pada sediaan tersebut menunjukan angka 0 absolut, sehingga seakan-akan membuktikan kemampuan kolostrum dalam penghambatan pelepasan ion sangat efektif, dan bahwa sama sekali tidak terdapat kandungan nikel pada kolostrum murni. Hasil yang berbeda ditunjukkan pada penelitian ini setelah dilakukan konservasi sediaan kolostrum, perendaman braket selama 7 hari sediaan kolostrum tidak berubah wujud dan pengukuran pelepasan ion dengan alat ICPOES pada larutan tersebut membuktikan adanya pelepasan ion $\mathrm{Ni}$.[27]

Hasil pelepasan ion pada kelompok kolostrum terfermentasi dan kelompok kolostrum dengan potassium sorbat lebih kecil dibandingkan dengan kelompok lain, Larutan kolostrum tersebut sebelum dilakukan pengukuran, terlebih dulu dilakukan proses destruksi basah dengan pemberian asam nitrat $\left(\mathrm{HNO}_{3}\right)$ dalam wadah terbuka selama 1 minggu. Hal ini memungkinkan kandungan ion menguap sebelum pengukuran. Pemberian asam nitrat $\left(\mathrm{HNO}_{3}\right)$ yang bersifat asam kuat mampu merusak kandungan kolostrum. Pelepasan ion yang rendah pada kedua kelompok kolostrum kemungkinan juga dapat disebabkan oleh proses destruksi basah tersebut. Proses destruksi basah menyebabkan hilangnya ion Fe sehingga tampak bias nilai kandungan Fe pada analisa menggunakan ICP-OES. Destruksi basah merupakan metode ekstraksi logam pada larutan yang dilakukan dengan peleburan asam mineral pekat dan zat-zat pengoksidasi kuat sehingga memutus ikatan antara senyawa organik dengan logam yang dianalisis. Proses destruksi dalam wadah terbuka memungkinkan penguapan pelarut sehingga menyebabkan kemungkinan terdapat ion logam Fe belum terambil dan juga kemungkinan logam Fe hilang.[28]

\section{SIMPULAN}

Kolostrum dengan potassium sorbat 0,5\% mampu menghambat terjadinya pelepasan ion Ni. Kolostrum terfermentasi memiliki daya hambat pelepasan ion $\mathrm{Ni}$ walaupun lebih lemah dibanding kolostrum dengan potassium sorbat $0,5 \%$. Kedua perlakuan kolostrum mampu menjaga konsistensi dan keberadaan substrat selama penelitian sehingga mampu mempertahankan daya hambat pelepasan ion Ni dalam jangka waktu tertentu.

Pengembangan penelitian masih perlu dilakukan untuk mengkonfirmasi hasil peneilitian tersebut dengan metode dan alat ukur lain seperti spektrofotometer UV-Visible, dan mengukur pelepasan ion lain pada braket stainless steel.

\section{DAFTAR PUSTAKA}

Abelev E, Smith AJ, Hassel A, Yair Ein-Eli Y. 2007. Potassium sorbate solutions as copper chemical mechanical planarization (CMP) based slurries. Electrochim Acta. 52:5150-5158.

Beech I, Bergel A, Mollica A, Flemming H, Scotto V, Sand W. 2000. Simple Methods for the Investigation of of the Role of Biofilms in Corrosion. 1-27 
Bourke J, Coulson I, English J. 2009. Guidelines for the management of contact dermatitis : an update. Brit J Dermatology. 160:946-954

Dinu M, Tarcolea M, Gherghhilescu AI, Cotrut CM. 2015. Influence of $\mathrm{pH}$ value and $\mathrm{NaF}$ addition on the corrosion behavior of $\mathrm{Ni}-\mathrm{Cr}$ and $\mathrm{Co}-\mathrm{Cr}$ dental alloys. UPB Sci Bull.77(2):149-158.

Fatimah S, Soekarsono, Prihandini I. 2013. Pelepasan ion nikel pada braket stainless steel baru dan daur ulang dalam saliva buatan (Pemeriksaan Laboratorium). J Ked Gi. 4(4):283-289.

Ferreira LS. 2013. Colostrum silage : fermentative, microbiological and nutritional dynamics of colostrum fermented under anaerobic conditions at different temperatures. Acta Sci Anim Sci. 35(4):395-401.

Godden, SM. 2009. Microbial Hazards Associated with Feeding Colostrum. www.dairyweb.ca/Resources / SWNMC2009/Godden.pdf

Gresfullah AZ, Aditya G. 2017. Pengaruh Kolostrum Terhadap Pelepasan Ion Metal (Ni, Cr Dan Fe) Pada Braket Metal Ortodonti. http://repository. unissula.ac.id/10086/

Heravi F, Moayed MH, Mokhber N. 2015. Effect of Fluoride on Nickel-Titanium and Stainless steel Orthodontic Archwires: An In-Vitro Study. J Dent. 12(1):49-59.

Jakfar S, Andriany P, Irawan B, Triaminingsih S. 2010. Pengaruh konsentrasi fluor dan $\mathrm{pH}$ pasta gigi terhadap pelepasan ion logam dari permukaan logam paduan. Dentika.15(2).

Kolokhita IE, Chatzistavrou E. 2009. A Severe Reaction to Ni-Containing Orthodontic Appliances. Angle Orthod. 79(1):186-192

Kristianingsih R, Joelijanto R, Praharani D. 2014. Analisis Pelepasan Ion Ni dan Cr Kawat Ortodontik Stainless steel yang Direndam dalam Minuman Berkarbonasi. Artik Ilm Has Penelit Mhs. 4

Lee T. 2010. Corrosion Resistance of Different Nickel-Titanium Archwires in Acidic Fluoride-containing Artificial Saliva. Angle Orthod. 80(3):547-553.

Leite LP, Bell RA. Adverse Hypersensitivity Reactions in Orthodontics. 2004. Semin Orthod. 9(2):240-243.

Linzell JL, Peaker M. 1974. Changes in colostrum composition and in the permeability of themammary epithelium at the time of parturition in the goat. J Physiol. 243(1):129-151.

Minanga MA, Anindita PS, Juliatri. 2016. Pelepasan Ion Nikel dan Kromium Braket Ortodontik Stainless steel yang Direndam Dalam Obat Kumur. PHARMACON. 5(1):135-141.

Naschan M, Tri A, Sumarni W. 2017. Uji Validitas Analisis Fe dalam Sedimen Sungai Kaligarang dengan FAAS dan ICP-OES. Indones J Chem Sci. 6(1):11-18.

Oh KT, Choo SU, Kim KM, Kim KN. 2005. A stainless steel bracket for orthodontic application. Eur J Orthod. 27(3):237244.

Posadas SJ, Pichler WJ. 2007. Delayed drug hypersensitivity reactions - New concepts. Clin Exp Allergy.37(7):989-999.

Rani BEA, Basu BBJ. 2012. Green inhibitors for corrosion protection of metals and alloys: An overview. Int J Corros. 1-15.

Roediger B, Weninger W. 2011. How nickel turns on innate immune cells. Immunol Cell Biol.89(1):1-2.

Sari, S.N, Suhaidi, I., Nainggolan, R.J. 2015. Pengaruh Perbandingan Bubur Buah Tomat dengan Sari Ubi Jalar Oranye dan Konsentrasi Kalium Sorbat terhadap Mutu Saos Pepaya. 
J.Rekayasa Pangan dan Pert. 3(3): 323-329

Sitohang NN, Roesyanto ID. 2014. Alergen penyebab dermatitis kontak pada pekerja salon di kecamatan Medan Baru. http://repository. usu.ac.id/bitstream/handle/ 123456789 / 41556/Abstract. pdf? sequence $=6 \&$ isAllowed $=y$

Siwy CJ, Tendean LEN, Anindita P. 2015. Uji Pelepasan Logam Kromium (Cr) dan Nikel (Ni) Beberapa Merek Braket Stainless steel dalam Cairan Saliva Artifisial. J e-Gigi. 3(2):1-5.

Sumule I, Anindita PS, Waworuntu OA. 2015. Pelepasan Ion Nikel dan Kromium
Braket Stainless steel yang Direndam Dalam Minuman Berkarbonasi. J e-Gigi. 3(2):1-6.

Thyssen JP, Menné T. 2010. Metal Allergy - A Review on Exposures, Penetration, Genetics, Prevalence, and Clinical Implications. Chem Res Toxicol. 23(2):309-318.

Toskovic DV, Rajkovic R, Stanojevic DD. 2005. Impact of additives on corrosion rate of cans filled with pieces of apricot. J Agric Sci. 50(1):63-71.

Travess H, Roberts-Harry D, Sandy J. 2004. Orthodontics. Part 6: Risks in orthodontic treatment. $\mathrm{Br}$ Dent J. 196(2):71-77. 